\title{
lentigo maligna
}

\section{悪性黒子}

川端 康浩*

\section{Lentigo maligna}

Yasuhiro KAWABATA *

* Department of Dermatology, Faculty of Medicine, University of Tokyo

A lentigo maligna can be defined as an early stage of lentigo maligna melanoma or a lentigo maligna melanoma in situ. It doesn't occur frequently in comparison with the other subtypes of malignant melanomas. Dermoscopy is very useful in early and correct diagnosis of malignant melanoma, allowing us to evaluate the structure of the surface profiles of pigmented skin lesions in detail. As for treatment, early diagnosis is the best treatment of malignant melanoma because an advanced malignant melanoma is usually incurable. [Skin Cancer (Japan) 2003 ; 18 : 126-130]

Key words: Lentigo maligna, Dermoscopy, Early diagnosis and treatment

本題に入る前に, 悪性黒子について, 本論文 中での定義について確認する。本邦では, 一般 に悪性黒色腫は下記の 4 型に分類されて論じら れている。

1 ）悪性黒子型悪性黒色腫

(Lentigo Maligna Melanoma)

2 ) 表在拡大型悪性黒色腫

(Superficial Spreading Melanoma)

3 ) 末端黒子型悪性黒色腫

(Acral Lentiginous Melanoma)

4 ) 結節型悪性黒色腫

(Nodular Melanoma)
そして, それぞれ特徴的な臨床, 病理組織像 を呈し, 生物学的態度や予後も異なるとされて いる。一方で,メラノーマはメラノーマである。 4 つの亜型に分類する意味はない, とする考え もある。本論文では, 便宜上, 上記の 4 型分類 に基づき, 墨性黒子を悪性黒子型悪性黒色腫の 表皮内病変 (Lentigo Maligna Melanoma in situ) ないし結節や潰瘍形成のない早期の悪性黒子型 悪性黒色腫と定義する。

* 東京大学医学部皮膚科学教室 


\section{疫学}

日本皮膚外科学会による悪性黒色腫の Group Study の最新データによれば，全症例 1538 例 中, 悪性黑子型悪性黒色腫は 102 例, $6.6 \%$ で, 悪性黑色腫 4 型のなかで, 最も発生頻度は低かっ た。男女比は約 $1 ： 2$, 平均年齢は 65.8 歳で, 全体の平均年齢が 59.3 歳なので, 他の病型に 比べると高齢者に多かった。また，84 例が顔 面を中心とした頭頸部発生例であった ${ }^{11}$ 。

当科における過去 12 年間の統計でも，悪性 黒子型悪性黑色腫は 39 例中 4 例（約 $10 \%$ ）で, そのうち 2 例が悪性黒子であった。

石原による悪性黒色腫の全国アンケート調査 では，悪性黒子型悪性黒色腫の発生頻度は約 $9.5 \%$ で，4 病型中最も低く，新鮮例での 5 年 生存率は $89.6 \%$ と 4 病型の中で, 最も高い生 存率を示していた。また，その後の追跡調査に よっても，10 年生存率は $80.1 \%$ と, 表在拡大 型悪性黒色腫と並んで高い生存率を示してい た ${ }^{2 !}$ 。

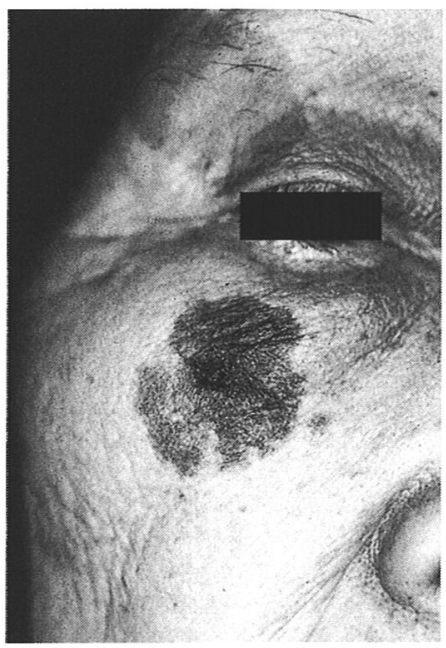

図 1a. 90 歳，女性. 右㚘部の悪性黒子型悪性黒色腫 の典型例. 10 数年来の「シミ」の一部が盛り 上がってきたということで受診した

\section{診断}

悪性黒子の診断においても，他の早期悪性黒 色腫と同様に, $\mathrm{ABCD}$ rule が適用される。 つまり，肉眼的な悪性黒色腫の鑑別のポイン トとして非対称性 (Asymmetrical configuration), 辺縁不整 (Border irregurality), 色 調の不均一性 (Color variegation), 直径ない し増大傾向（Diameter enlargement）をチェッ クする (図 1a～2)。しかし，このような簡便 な鑑別法では，おのずから診断精度に限界があ る。そこで，最近はDermatoscopeなどの Epiluminescence microscope が実際の診療の 場でも色素性病変の診断に活用されるようにな

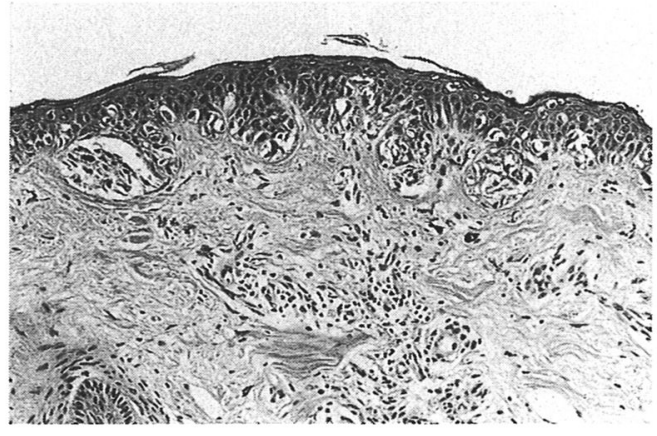

図 1b. 黒色斑の部分の病理組織像. 表皮内にメラノサ イトの不整形の胞巣形成と孤立性増殖を認める

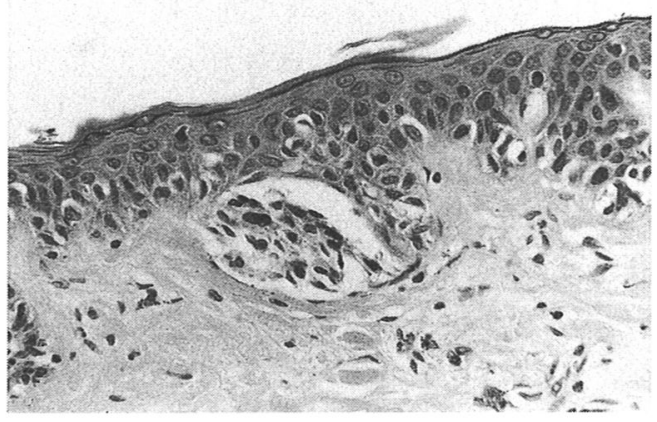

図 1c. 個々の腫瘍細胞には異型性が認められる。 この症例はstage II で, 辺縁より約 $1 \mathrm{~cm}$ 離して, 切除し, 全層植皮を行った。年齢を考慮して化 学療法は行わなかった 


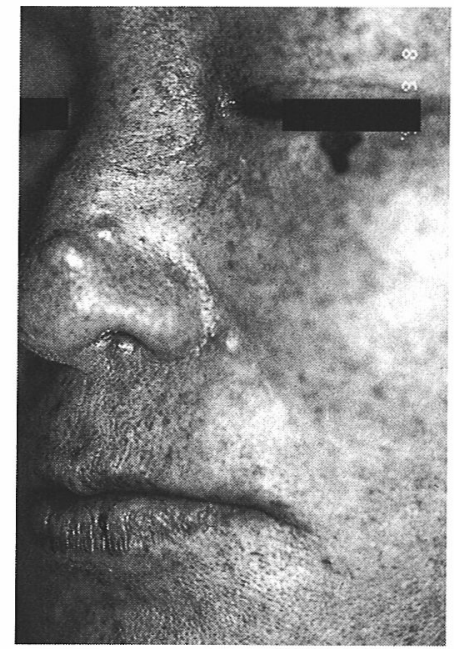

図 2.54 歳, 女性, 色素性乾皮症 variant 患者 若年期から日焼け止めを徹底していたのにもか かわらず，左下眼瞼に悪性黒子が発症した。鼻 部の腫瘍は無色素性の基底細胞癌だった。悪性 黒子の発症には, 日光, 紫外線曝露が大きく関 与しているといわれているが，このような症例 は悪性黒子の光発癌を示唆するものと思われる

ってきた。これは病変部を拡大するとともに, 超音波ゼリーの油浸により透光性を増大させ た皮膚表面に強い光源をあてて真皮上層程度ま での色素沈着の様子を観察する機器である。本 邦では，未だ普及度は低いものの，欧米では既 に色素性疾患の診断には必要不可欠な機器とな っている ${ }^{3)}$ 。

悪性黑子病変部の Dermoscopy 所見の特徵 は，白く抜けた毛包や汗管周囲を取り巻くよう な色素沈着によって形成される，いわゆる pseudopigment network が非常に不規則に分布 し，辺縁部では放射状，分枝状に配列すること である4（図 3，4）。体幹にみられるような pigment network を構成しないのは顔面では, 表皮突起が平坦化しているからだといわれてい る。しかし，Dermoscopyによる悪性黒色腫の 診断では辺縁の streaks や network 構造に目が いきがちだが，全体的な色調の不均一性，多様 性も重要な要素である。

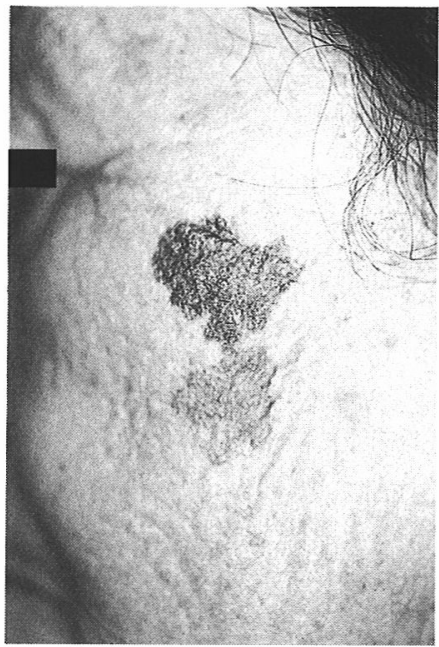

図 3a. 76 歳，女性，悪性黑子典型例

非対称形，辺縁不整，色調が不均一で，大きさ も長径が $4 \mathrm{~cm}$ 以上あり，ABCD rule に合致し， 肉眼的視診のみで，迷いなく確定診断を下すこ とができる

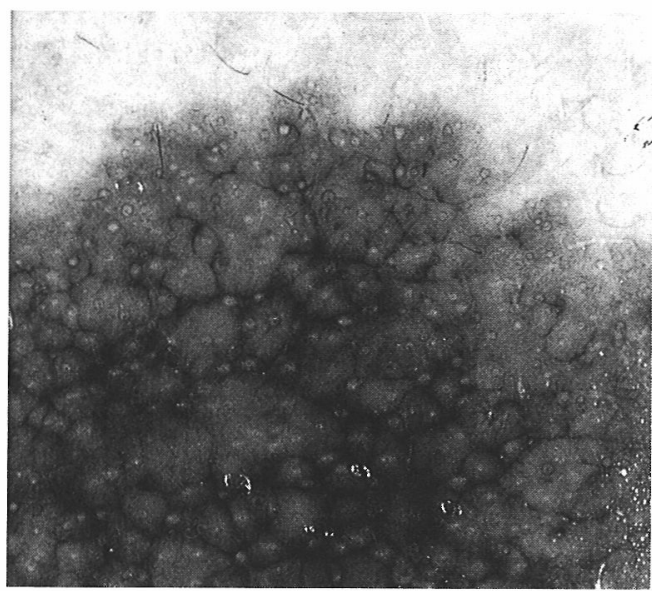

図 3b. 図 3a の Dermoscopy

白く抜けた毛包や汗管周囲を取り巻くような色 素沈着によって形成される，いわゆる pseudopigment network が非常に不規則に分布 し，辺縁部では放射状，分枝状に配列している

\section{治療}

悪性黒子型悪性黒色腫は高需者に多いため, 強力な治療を行うことは少ない。しかし，悪性 黒子型悪性黒色腫でも壮年者の進行例であれ 


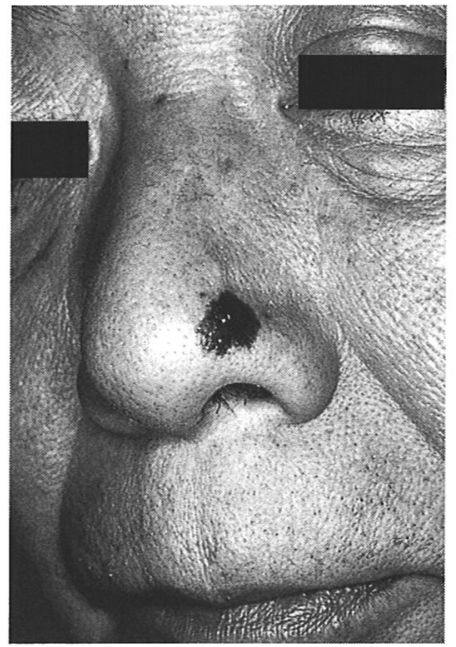

図 4a. 57 歳, 男性. 左鼻翼の悪性黒子型悪性黒色腫

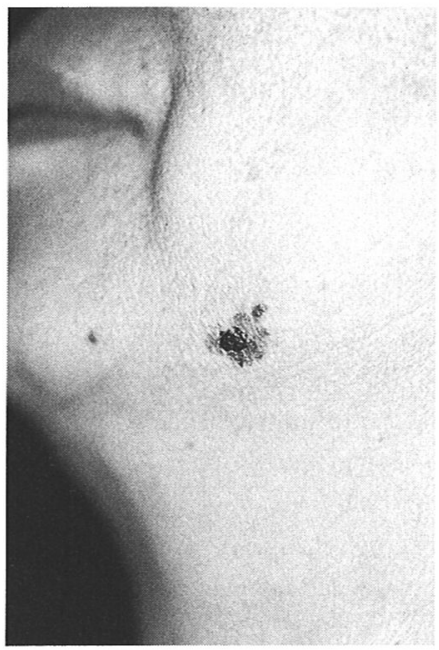

図 5a.75歳，女性. 下顎の悪性黒子

ば，他の病型の進行例と同じく，原発巣の拡大 切除, 所属リンパ節郭清, 化学療法, 免疫療法 (インターフェロンなど) を組み合わせた集学 的治療の適応となる。

それに対して，悪性黒子，つまり早期病変で あれば，単に原発巣を辺縁より $1 \mathrm{~cm}$ ほど離し

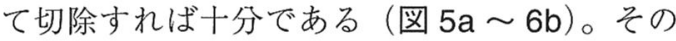
うえ, 予後的にも早期例と進行例の差は歴然と

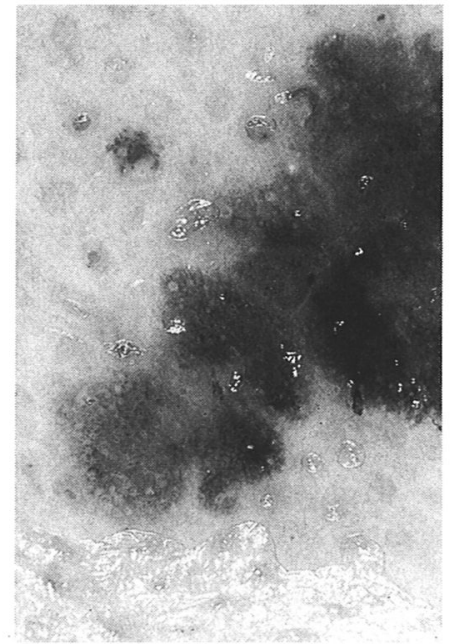

図 4b. Dermoscopy では, 太く不規則な network 構造 にblue-grey veil が混在している。 また, 病変 が一部スキップして存在している

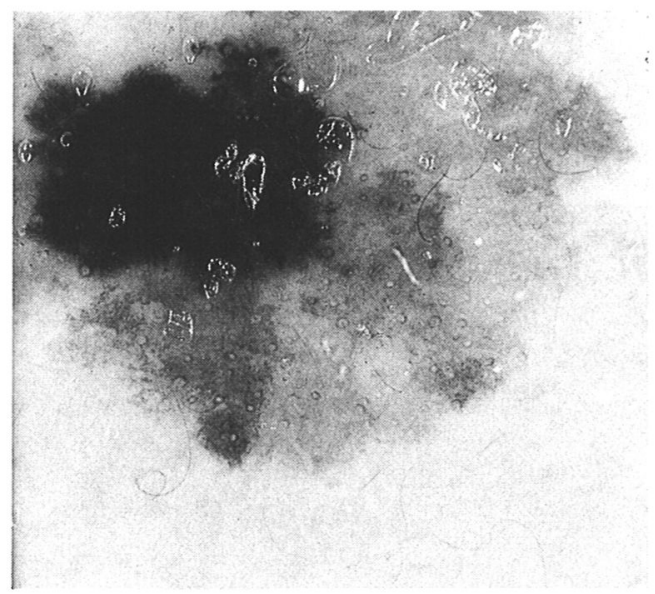

図 5b.Dermoscopy ではびまん性，無構造な黒褐色色 素沈着部分と濃褐色, 淡褐色で不規則な network 構造を示す部分とがみられる

している。つまり，「早期発見に勝る治療なし」 と言えるわけである ${ }^{5)}$ 。

今後, 社会の一層の高齢化によって, 悪性黒 子患者についても増加していくことが予想され る。我々皮膚科医も早期診断, 早期治療のため, 診断能力の向上と社会の啓蒙に努力していく必 要があるだろう。 


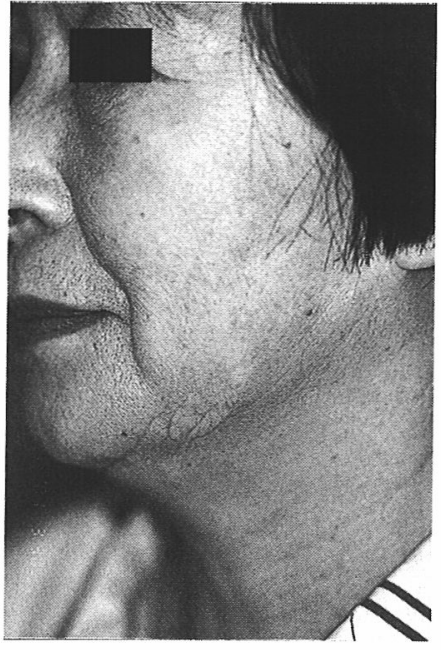

図 5c. 結節形成などはなく, 組織学的に melanoma in situだったので, 辺縁より $5 \mathrm{~mm}$ 離して切除・ 植皮し，術後 5 年でほとんど傷跡も目立たなく なった

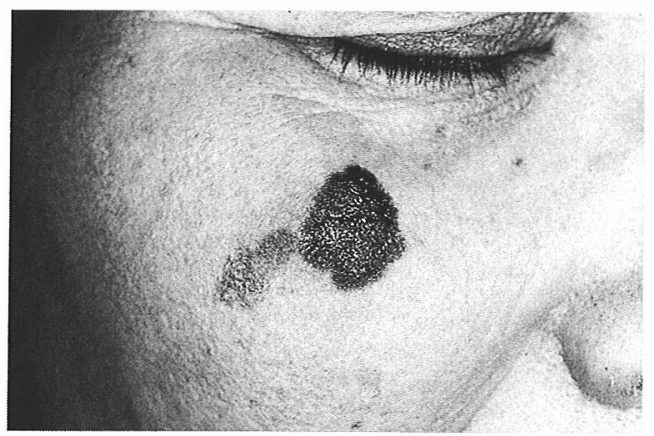

図 6a. 54 歳, 女性. 右煩部の悪性黑子型覀性黒色腫. 黒色斑のほぼ中央部に小結節を認め, stage II だった

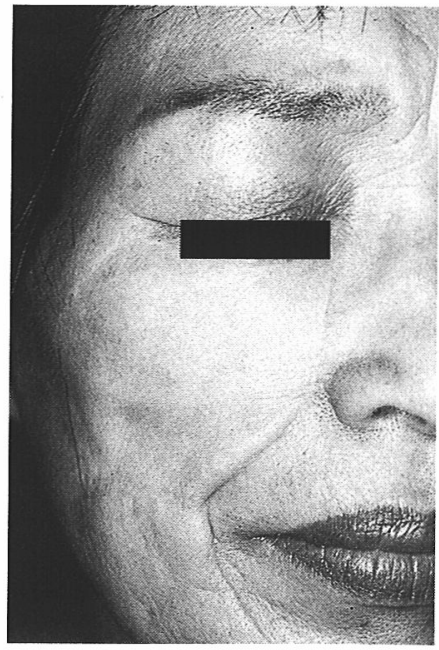

図 6b. 治療はエステティックサブユニットプリンシプ ルに従った拡大切除のみで, 術後化学療法も行 わず，術後 10 年以上生存している

\section{文献}

1）日本皮䖉外科学会・悪性黒色腫の Group Study デー 夕・ベース

2) 石原和之, 斎田俊明, 山本明史：悪性黑色腫 （1987～1991 年）の統計調査による疫学, 予後因 子, 10 年生存率. Skin Cancer, 15:99-107, 2000

3) Soyer HP, Smolle J, Hodl S, et al : Surface microscopy: a new approach to the diagnosis of cutaneous pigmented tumors. Am J Dermatopathol, 11:1-10, 1989

4) Pehamberger $\mathrm{H}$, Binder $\mathrm{M}$, Steiner $\mathrm{A}$, et al : In vivo epiluminescence microscopy-improvement of early diagnosis of melanoma. J Invest Dermatol, 100 (3) : 356-362, 1993

5 ）川端康浩, 玉置邦彦：皮膚悪性腫瘍の術前・術後 の留意点一皮膚科医の視点から一, 日皮会誌, 110： 1537-1542, 2000 


\section{「悪性黒子」に対するコメント}

\section{札幌医科大学皮膚科学講座 教授 神保 孝一}

悪性黒子（lentigo maligna: LM）は，悪性黑色腫の表皮内病変（melanoma in situ）であるが，悪 性黒色腫の病変が水平増殖巣に限局したもので黒色腫の早期病変を示す。この悪性黒子という言葉 が悪性黒子型悪性黑色腫の早期病変として位置づけられる場合と他の悪性黒色腫（例えば，末端黑 子型悪性黒色腫）の早期病変（melanoma in situ）を指す場合と 2 つが考えられる。一般的に悪性黒 子型悪性黒色腫の早期病変を意味すると考えられてはいるが, 末端黑子型悪性黒色腫の早期病変も 通常，同一のものと考えてよいと考光る。

顔面における悪性黒子型悪性黒色腫等の早期病変（悪性黒子）が dermoscopy の観察下にて汗孔・ 毛包開口部を中心とした網目様構造を呈し，これらが他の悪性黒色腫の早期病変部とは異なるパター ンを示すということは極めて興味ある所見である。悪性黒色腫の母細胞は表皮メラノサイトである が，このメラノサイトは，表皮内に存在するメラノサイトが癌化する場合と皮膚・附属器（例えば 汗管・毛包等）に存在するメラノサイトの幹細胞が表皮へ移動し悪性黒色腫細胞へと変化する場合 と 2 通りが考えられる。そういった意味で, 顔面の悪性黒子型悪性黒色腫の早期病変が汗孔・毛包 開口部に網目様構造をとることは幹細胞から悪性黒色腫の幹細胞が発症する可能性も否定できず, これらの事に関しては, 更に今後の研究課題の一つとして検討する余地がある。

このような汗孔・毛包開口部を中心とした網目様構造が末端黒子型悪性黒色腫には認められない が, 将来的には, 悪性黒子型悪性黒色腫と末端黒子型悪性黒色腫の病因・病態を考える場合, 殊に 黒色腫細胞の母細胞を考える場合, 極めて興味ある所見となりえる。今後は, 個々の黒色腫細胞の 遺伝子解析（例えば， comparative genomic hybridization や FISH 等）の技術を用いてどのような遺 伝子変異を示すか, DNA コピー数の変化を引き起こすか等を検索すると更に明確に悪性黒色腫病 因・病態に関しての新しい知見が得られることが期待される (Pigment Cell Res 15 (suppl 9): 53, 2002)。また，最近 Cycline D 1 が皮膚のメラノーマの oncogene の candidate として報告されたが (Sauder FR et al, Cancer Res 62: 3200, 2002)，こういったマーカーの検索も悪性黒子の母細胞を解析 する一つの方法かもしれない。今後の検索が期待される。 